\title{
Calculation of Unit Cost School Information System Development using ABC (Activity Based Costing) Method
}

\author{
Muhammad Fahson Hakim*, Ahmad Sirojun Nuha**, Widya Aini Lathifah***, M. Ainul Yaqin**** \\ Jurusan Teknik Informatika, Fakultas Sains dan Teknologi \\ Universitas Islam Negeri Maulana Malik Ibrahim Malang \\ Jl. Gajayana. 50 Lowokwaru Malang \\ Email:156650093@student.uin-malang.ac.id*,16650093@student.uin-malang.ac.id**, \\ 316650095@studenet.uin-malang.ac.id***, yaqinov@ti.uin-malang.ac.id*****
}

\begin{abstract}
In developing an information system the school must determine a strategy in its development. Look for managers who are reliable in making decisions that are oriented to reliable development. One of the proper management concepts is cost accuracy. Accuracy of charging costs on cost objects is very important for users of cost information. Beside the accuracy, it is also needed to find out the cost per unit needed in the information system. This is intended to have a price benchmark for the development of information systems in the future. In this study the unit cost calculation uses the $\mathrm{ABC}$ (Activity Based Costing) method which emphasizes the cost calculation for the activities involved. The allocation of costs is based on salary data from trusted institutions, namely the Pedoman Standard Minimal 2019 by INKINDO. The results of this study get a total cost value of $18.407 .082,00$ while the cost of each complexity is 5,301.00 with the standard cost of procurement of goods and services issued by the government and several survey institutions.
\end{abstract}

Keyword: cost, accuracy, calculation, Activity Based Costing

\section{INTRODUCTION}

Education is very important to educate the nation's life. One of the providers of Education is the school. Schools are required to utilize and maximize the available staff and infrastructure. So that the school is able to provide the best academic services. Utilization of various technologies and experts will certainly cost more operational costs as well. Therefore it is necessary to maximize school finances.

In Indonesia at this time most schools only rely on the manual academic system in carrying out education, ranging from academic acceptance, the KBM process, financial management, etc. If this continues, it will add to the complexity of the process and physical activity in the school. This needs to be supported by the use of technology that is growing today. One way to make the process in schools effective is by developing information systems that can be accessed by all parties online. Therefore, it is necessary to hold a school information system. Online-based information system will facilitate all activities involved in school. In addition to reducing physical activity, it also reduces cost reductions such as communication, stationery etc.

In developing an information system the school must determine a strategy in its development. Look for managers who are reliable in making decisions that are oriented towards reliable development. One of the proper management concepts is cost accuracy. Accuracy of charging costs on cost objects is very important for users of cost information. Cost accuracy is also needed to anticipate overhead that can occur without careful calculation. In addition, the determination of costs must also be based on available sources, such as SBU (Standard Biaya Umum/General Cost Standard) and other costs referred to by the official party. It is intended that the cost estimate is not just an estimate or input from parties who take advantage of the opportunity for profit.

Developing a school information system is certainly related to costs. Appropriate cost allocation is needed so that finance is well managed. Therefore, the authors analyze the unit cost (unit cost) with the $\mathrm{ABC}$ model (Activity Based Costing) to determine the standard costs of developing information systems. The ABC method bases the calculation of costs on the imposition of activity costs, so that the resulting costs are the result of the costs of all activities carried out on the development of Information Systems. In addition, costs can also be calculated for each complexity, as the complexity of information systems is a standard unit in the software world. So that in addition to getting prices and costs for the development of information systems can also be a reference for the development of other information systems that only use the value of its complexity. It is expected that schools can manage finances for developing information systems effectively.

Generally, the calculation of costs by the ABC method, namely: determine the initial costs for product development. After that the costs are allocated to all existing activities. Once obtained, the activity costs are calculated for each unit. Costs are also calculated based on the scale of complexity. 


\section{Literature Review}

\section{Cost}

Cost (cost) is defined as a resource that is sacrificed (sacrified) or released (forgone) to achieve certain goals. A cost is usually measured in units of money that must be spent in order to get goods/services.In the context of education, Nanang Fattah defines "Education costs as the amount of money generated and spent for various purposes of organizing Education (Nanang, 2009).

\section{School}

According to KBBI School is a building or institution for learning and teaching and a place to receive and give lessons (according to level, there is).

\section{System Development}

System development/application development is developing a solution to business problems using an information syste/software (O'Brien and Marakas, 2011). Software development is usually used by the project approach (project approach). Projects are defined as a collection of activities with clear start and end to achieve organizational goals (Laudon, 2014; O'Brien and Marakas, 2011). Every project has limitations, both in terms of budget and time. For this reason, the project needs to be managed so that the target can be achieved with a certain budget and time. Existing activities in project management are planning, risk assessment, cost estimation, gathering needed resources, organizing work, directing, controlling project execution, reporting progress, and analyzing results (Laudon, 2014)

\section{Information Systems}

Information systems are interrelated components that work together to collect, process, store, and display information to support decision making, coordination, regulation, analysis, and visualization in an organization (Laudon, 2016).Information system is a system within an organization that meets the needs of daily transaction processing that supports the managerial functions of an organization's operations with the strategic activities of an organization to be able to provide certain external parties with the reports that are needed. (Sutabri, 2012: 46)

According to Whitten, Bentley, and Ditman (2009: 10) information systems are arrangements of people, data, processes, and information (IT) or information technology that interact to collect, process, store, and provide as output the information needed to support an institution. or organization.

\section{METHODOLOGY}

The method used in the study is as follows below.

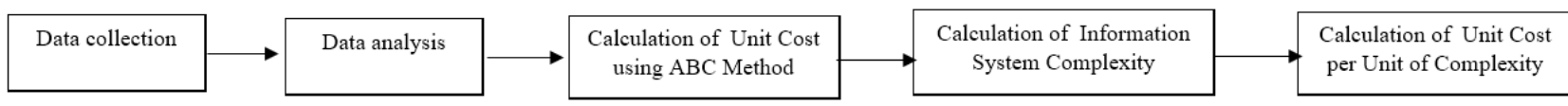

Figure 1. Flow of Research Methods.

\section{Data collection}

Data collection is a way to gather information, data, facts related to research. There are 2 kinds of data collection in this study, namely primary and secondary data. Primary data collection is from documentation and literature studies, secondary data is from interviews. The explanation is as follows:

1. Literature Study

Literature study that is by reading, understanding, analyzing the research that has been done in order to find the theoretical basis that will be conducted to analyze in this study.

2. Documentation

Documentations are written items, archives related to this research, such as employee salary data, etc.

\section{Interview}

The interview is looking for sources in the form of oral sources obtained from experts who understand about research in order to expedite the research process.

\section{Data analysis}

The data that has been obtained is then analyzed, starting from the creation of a Class Diagram as a source for determining information system units. In addition, class diagrams are also applied to web services and will be used to determine the scale of complexity. The class diagram is as follows. 
Figure 2. Academic Class Diagram.

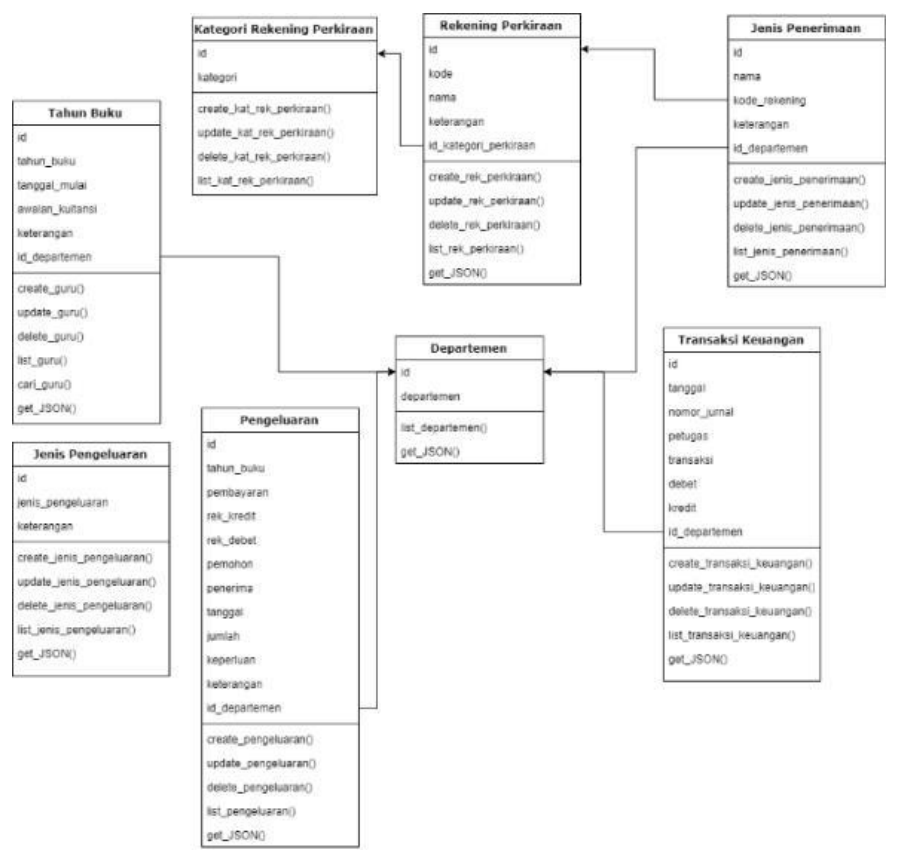

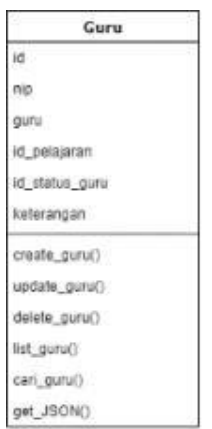

\begin{tabular}{|c|}
\hline Pelajaran \\
\hline 14_pelijistan \\
\hline singkaten \\
\hline namo \\
\hline stat \\
\hline keterengan \\
\hline status \\
\hline create_cosijarano \\
\hline update_elajacano \\
\hline delese_pelajaran0 \\
\hline Ist__eltajaran 0 \\
\hline get (J9ON) \\
\hline
\end{tabular}

\begin{tabular}{|l|}
\hline \multicolumn{1}{|c|}{ Jam } \\
\hline id \\
wastu \\
\hline Create_jam0 \\
update_jam0 \\
delete_Jarn() \\
ist_jam0 \\
get_JsoN) \\
\hline
\end{tabular}

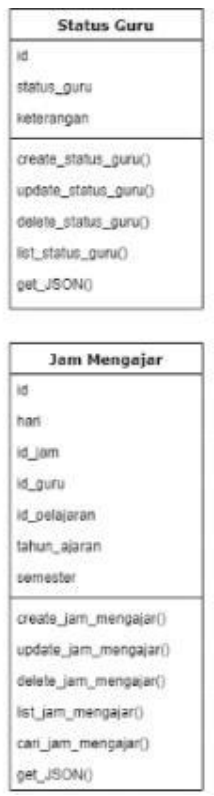

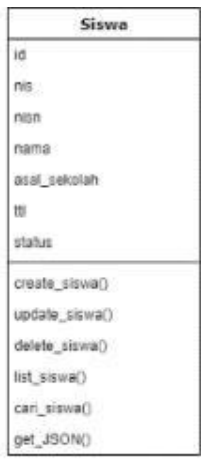

Figure 3. Accounting Class Diagram.

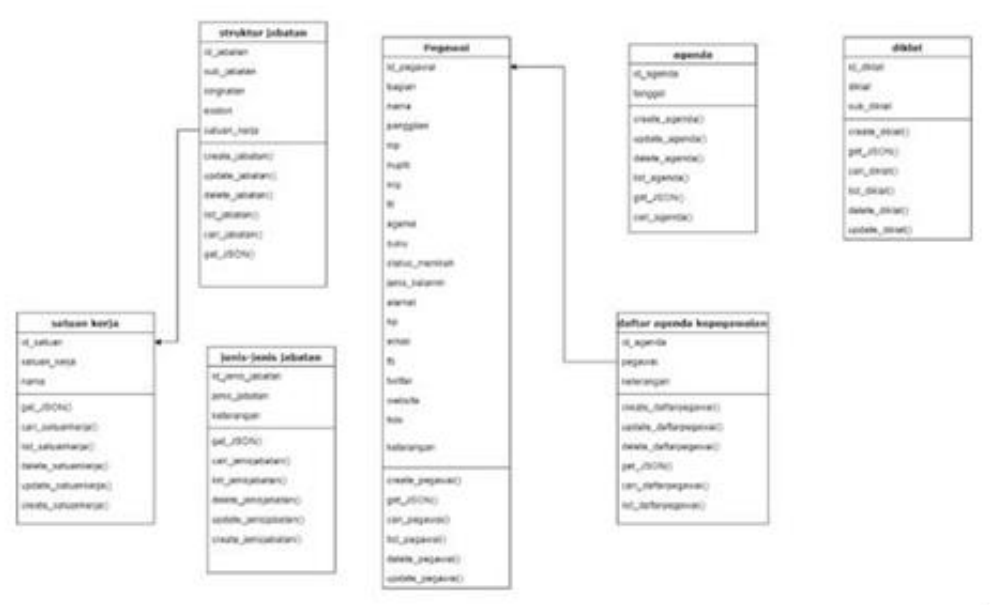

Figure 4. Staff Class Diagram. 


\section{Calculation of Unit Cost Using ABC Method}

The Unit Cost calculation stage with the ABC method is as shown below:

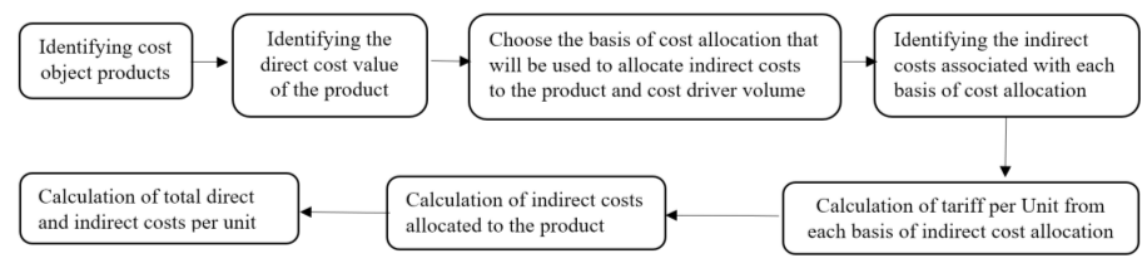

Figure 5. Flow of ABC Method.

1. Identifying cost object products.

2. Identifying the direct cost value of the product

3. Choose the basis of cost allocation that will be used to allocate indirect costs to the product and cost driver volume

4. Identifying the indirect costs associated with each basis of cost allocation

5. Calculation of tariff per Unit from each basis of indirect cost allocation

6. Calculation of indirect costs allocated to the product

7. Calculation of total direct and indirect costs per unit

\section{Calculation of Information SystemsComplexity}

The scale of complexity is of many kinds, one of which is code complexity representing the level of code complexity in a program. In general, program code is represented based on the Object Oriented Programming (OOP) standard. Based on OOP, the structure of program code can be configured in the form of class diagrams. Class diagrams consist of methods (Methods), attributes (Attributes), and relations (Relationships). Codescale can be formulated as follows:

Codescale $=\left(\begin{array}{ll}0.637 & \left.\sum \sum \text { Method }\right)+(0.258\end{array}\right.$ $\cdot \sum$ Attribute $)+\left(0.105 \cdot \sum\right.$ Relation $)$

\section{Calculation of Unit Cost per Unit Complexity}

The main objective of this research is to find out the Unit Cost for the school information system based on its complexity. The total costs that have been obtained from $\mathrm{ABC}$ calculations are finally divided by the measured complexity, both from the method, the business process or the code. And in this research the code complexity is used.

\section{RESULT AND DISCUSSION}

\section{Calculation of Unit Cost by ABC Method}

\section{Identifying cost object products.}

Table 1. Product (Information System) that Become Cost Object.

\begin{tabular}{llc}
\hline No. & Information System Type & Number of Units \\
\hline 1. & Admin Dashboard System (ADS) & 5 \\
2. & Student Dashboard System (SDS) & 4 \\
3. & Staff Dashboard System (StDS) & 4 \\
4. & Infrastructure Management (IM) & 4 \\
5. & Finance Management (FM) & 5 \\
6. & General Journal (GJ) & 3 \\
7. & School Management (SM) & 4 \\
8. & Finance Report (FR) & 3 \\
9. & Recapitulation (Rc) & 3 \\
10. & User Management (UM) & 2 \\
11. & Application Management (AM) & 2 \\
\hline
\end{tabular}

\section{Identifying the direct cost value of the product}

Table 2. Value of Product Direct Cost.

\begin{tabular}{ccccccc}
\hline No. & IS Type & Direct Cost (IDR) & Development Time (Hour) & Consumption Cost (IDR) & Main Cost & \%time \\
\hline 1. & ADS & $750.000,00$ & 30 & $250.000,00$ & $1.000 .000,00$ & $15 \%$ \\
2. & SDS & $500.000,00$ & 12 & $100.000,00$ & $600.000,00$ \\
3. & StDS & $650.000,00$ & 26 & $200.000,00$ & $850.000,00$ \\
4. & IM & $550.000,00$ & 24 & $400.000,00$ & $950.000,00$ \\
5. & FM & $575.000,00$ & 23 & $350.000,00$ & $13 \%$ \\
6. & GJ & $450.000,00$ & 15 & $250.000,00$ & $700.000,00$ \\
7. & SM & $450.000,00$ & 20 & $100.000,00$ & $12 \%$ \\
8. & FR & $400.000,00$ & 16 & $250.000,00$ & $550.000,00$ & $10 \%$ \\
9. & Rc & $300.000,00$ & 10 & $400.000,00$ & $650.000,00$ & $8 \%$ \\
10 & UM & $350.000,00$ & 12 & $200.000,00$ & $700.000,00$ & $5 \%$ \\
11. & AM & $350.000,00$ & 12 & $200.000,00$ & $550.000,00$ & $6 \%$ \\
& TOTAL & $5.325 .000,00$ & 200 & $2.700 .000,00$ & $550.000,00$ & $6 \%$ \\
\hline
\end{tabular}


Classifying the cost of an object that becomes the cost of the object then the direct costs that have been set, then proceed to determine the value of the cost.
3. Choose the basis of cost allocation that will be used to allocate indirect costs to the product and cost driver volume.

Table 3. Identification of Activities and its Units.

\begin{tabular}{lll}
\hline No. & Activity & Unit \\
\hline 1. & Communication (C) & Communication Time (CT) \\
2. & Briefing (P) & Briefing Time (BT) \\
3. & System Analysis (SA) & Number of Process (NP) \\
4. & Design Frontend (DF) & Number of Design (ND) \\
5. & Program Documentation (PD) & Number of Document (NDoc) \\
6. & Write Help Guide (WH) & Number of Sheet (NS) \\
7. & Network Setting (NS) & Setting Time (ST) \\
8. & Coding System (CS) & Number of Method (NM) \\
9. & Implementation (I) & Number of Feature(NF) \\
10. & Testing (T) & Number of Testing (NT) \\
\hline
\end{tabular}

Table 4. The Basic Allocation of Costs That Will be Used to Allocate Indirect Costs.

\begin{tabular}{clcccccccccc}
\hline No. & IS Type & CT & BT & NP & ND & NDoc & NS & ST & NM & NF & NT \\
\hline 1. & ADS & 2 & 2 & 3 & 4 & 4 & 2 & 3 & 20 & 3 & 3 \\
2. & SDS & 2 & 2 & 3 & 4 & 4 & 2 & 3 & 20 & 3 & 3 \\
3. & StDS & 2 & 2 & 3 & 4 & 4 & 2 & 2 & 20 & 3 & 2 \\
4. & IM & 2 & 2 & 2 & 4 & 4 & 2 & 2 & 5 & 2 & 2 \\
5. & FM & 2 & 2 & 3 & 3 & 3 & 2 & 2 & 15 & 2 & 2 \\
6. & GJ & 1 & 1 & 2 & 2 & 2 & 1 & 1 & 10 & 1 & 1 \\
7. & SM & 2 & 2 & 3 & 4 & 4 & 2 & 1 & 5 & 2 & 2 \\
8. & FR & 1 & 2 & 2 & 2 & 2 & 2 & 1 & 10 & 1 & 1 \\
9. & Rc & 1 & 1 & 2 & 2 & 2 & 1 & 1 & 5 & 2 & 2 \\
10. & UM & 1 & 1 & 2 & 2 & 2 & 2 & 1 & 5 & 1 & 1 \\
11. & AM & 1 & 1 & 2 & 2 & 2 & 2 & 1 & 5 & 1 & 1 \\
& TOTAL & 17 & 18 & 27 & 33 & 33 & 20 & 18 & 120 & 21 & 20 \\
\hline
\end{tabular}

Each cost driver is specified for the amount and volume and value. The breakdown is based on the units used by each part of the information system.

\section{Identify the indirect costs associated with each basis of cost allocation}

Table 5. Indirect Costs Related to Each Basis of Cost Allocation.

\begin{tabular}{clr}
\hline No. & Activity & Cost \\
\hline 1. & C & $1.027 .083,00$ \\
2. & P & $600.000,00$ \\
3. & SA & $735.000,00$ \\
4. & DF & $1.733 .333,00$ \\
5. & PD & $671.666,00$ \\
6. & WH & $600.000,00$ \\
7. & NS & $1.605 .000,00$ \\
8. & CS & $2.700 .000,00$ \\
9. & I & $277.500,00$ \\
10. & T & $757.500,00$ \\
& TOTAL & $10.707 .082,00$ \\
\hline
\end{tabular}

Indirect costs come from workers' salaries obtained from reliable sources, one of which is the 2019 Minimum Standard Guidelines by INKINDO.
5. Calculate the rate per Unit from each basis of indirect cost allocation

Table 6. Tariffs per Unit of each basis of indirect cost allocation.

\begin{tabular}{|c|c|c|c|c|c|c|}
\hline No. & Activity & Cost & Volume & Unit & Pool Rate & Unit \\
\hline 1. & $\mathrm{C}$ & $1.027 .083,00$ & 17 & Hours & $60.416,65$ & $\begin{array}{l}\text { Per } \\
\text { Hours }\end{array}$ \\
\hline 2. & $\mathrm{P}$ & $600.000,00$ & 18 & Hours & $33.333,33$ & $\begin{array}{l}\text { Per } \\
\text { Hours }\end{array}$ \\
\hline 3. & SA & $735.000,00$ & 27 & Process & $27.222,22$ & $\begin{array}{l}\text { Per } \\
\text { Process }\end{array}$ \\
\hline 4. & DF & $1.733 .333,00$ & 33 & Sketch & $52.525,24$ & $\begin{array}{l}\text { Per } \\
\text { Sketch }\end{array}$ \\
\hline 5. & PD & $671.666,00$ & 33 & Sketch & $20.353,52$ & $\begin{array}{l}\text { Per } \\
\text { Sketch }\end{array}$ \\
\hline 6. & WH & $600.000,00$ & 20 & Sheet & $30.000,00$ & $\begin{array}{l}\text { Per } \\
\text { Sheet }\end{array}$ \\
\hline 7. & NS & $1.605 .000,00$ & 18 & Hours & $89.166,67$ & $\begin{array}{l}\text { Per } \\
\text { Hours }\end{array}$ \\
\hline 8. & CS & $2.700 .000,00$ & 120 & Method & $22.500,00$ & $\begin{array}{l}\text { Per } \\
\text { Method }\end{array}$ \\
\hline 9. & I & $277.500,00$ & 21 & Feature & $13.214,29$ & $\begin{array}{l}\text { Per } \\
\text { Feature }\end{array}$ \\
\hline \multirow[t]{2}{*}{10.} & $\mathrm{~T}$ & $757.500,00$ & 20 & Testing & $37.875,00$ & $\begin{array}{l}\text { Per } \\
\text { Testing }\end{array}$ \\
\hline & TOTAL & $10.707 .082,00$ & & & & \\
\hline
\end{tabular}

After getting the costs required for each activity, the activity costs are broken down again, so that a poll rate will be based on the price for each activity. 


\section{Calculate the indirect costs allocated to the product}

Table 7. Indirect costs allocated to the product.

\begin{tabular}{ccccccccccccc}
\hline $\begin{array}{c}\text { IS/ } \\
\text { Activity }\end{array}$ & ADS & SDS & StDS & IM & FM & GJ & SM & FR & RC & UM & AM & TOTAL \\
\hline C & 120.833 & 120.833 & 120.833 & 120.833 & 120.833 & 60.417 & 120.833 & 60.417 & 60.417 & 60.417 & 60.417 & 1.027 .0 \\
P & 66.667 & 66.667 & 66.667 & 66.667 & 66.667 & 33.333 & 66.667 & 66.667 & 33.333 & 33.333 & 33.333 & 600.000 \\
SA & 81.667 & 81.667 & 81.667 & 54.444 & 81.667 & 54.444 & 81.667 & 54.444 & 54.444 & 54.444 & 54.444 & 735.000 \\
DF & 210.101 & 210.101 & 210.101 & 210.101 & 157.576 & 105.050 & 210.101 & 105.050 & 105.050 & 105.050 & 105.050 & 1.733 .3 \\
PD & 81.414 & 81.414 & 81.414 & 81.414 & 61.061 & 40.707 & 81.414 & 40.707 & 40.707 & 40.707 & 40.707 & 671.666 \\
WH & 60.000 & 60.000 & 60.000 & 60.000 & 60.000 & 30.000 & 60.000 & 60.000 & 30.000 & 60.000 & 60.000 & 600.000 \\
NS & 267.500 & 267.500 & 178.333 & 178.333 & 178.333 & 89.167 & 89.167 & 89.167 & 89.167 & 89.167 & 89.167 & 1.605 .0 \\
CS & 450.000 & 450.000 & 450.000 & 112.500 & 337.500 & 225.000 & 112.500 & 225.000 & 112.500 & 112.500 & 112.500 & 2.700 .0 \\
I & 39.643 & 39.643 & 39.643 & 26.429 & 26.429 & 13.214 & 26.429 & 13.214 & 26.429 & 13.214 & 13.214 & 277.500 \\
T & 113.625 & 113.625 & 75.750 & 75.750 & 75.750 & 37.875 & 75.750 & 37.875 & 75.750 & 37.875 & 37.875 & 757.500 \\
TOTAL & 1.491 .45 & 1.491 .4 & 1.364 .4 & 986.471 & 1.165 .8 & 689.208 & 924.527 & 752.541 & 627.797 & 606.708 & 606.708 & 10.707. \\
& 0 & 50 & 08 & & 15 & & & & & & & \\
\hline
\end{tabular}

Pool rate is used to calculate the cost needed by multiplying the number of units in each activity.

\section{Calculate the total cost of each unit (direct cost and indirect cost)}

Table 8. The Total Cost of Each Unit Direct And Indirect.

\begin{tabular}{ccrrr}
\hline No. & IS Units & \multicolumn{1}{c}{$\begin{array}{c}\text { Direct } \\
\text { Cost }\end{array}$} & \multicolumn{1}{c}{$\begin{array}{c}\text { Indirect } \\
\text { Cost }\end{array}$} & Total Cost \\
\hline 1. & ADS & 1.000 .000 & 1.491 .450 & 2.491 .450 \\
2. & SDS & 400.000 & 1.491 .450 & 1.891 .450 \\
3. & StDS & 850.000 & 1.364 .408 & 2.214 .408 \\
4. & IM & 1.000 .000 & 986.471 & 1.986 .471 \\
5. & FM & 925.000 & 1.165 .815 & 2.090 .815 \\
6. & GJ & 625.000 & 689.208 & 1.314 .208 \\
7. & SM & 600.000 & 924.527 & 1.524 .527 \\
8. & FR & 650.000 & 752.541 & 1.402 .541 \\
9. & Rc & 650.000 & 627.797 & 1.277 .797 \\
10. & UM & 500.000 & 606.708 & 1.106 .708 \\
11. & AM & 500.000 & 606.708 & 1.106 .708 \\
\hline & TOTAL & $\mathbf{7 . 7 0 0 . 0 0 0}$ & $\mathbf{1 0 . 7 0 7 . 0 8 2}$ & $\mathbf{1 8 . 4 0 7 . 0 8 2}$ \\
\hline
\end{tabular}

The final result is a total cost IDR 18,407,082.00 which will be calculated based on its complexity.

\section{Calculation of IS Complexity}

Research with the title Pengukuran Metrik Kompleksitas Web Service Sekolah (Ahmad Riza et. Al., 2019) measures the complexity of the Information System code in the form of Web Service which is the same case as this research. The formula is as follows:

Codescale $=\left(0.637 \cdot \sum\right.$ Method $)+\left(0.258 \sum\right.$ $\sum$ Attribute $)+\left(0.105 \sum \sum\right.$ Relation $)$. The obtainedresults is measure the complexity of school Web Services ie. 3,472 .

\section{Calculation of Unit Cost per Unit of Complexity}

After getting the total cost, the cost per complexity is calculated. The total cost is IDR 18,407,082.00, while the complexity is $\mathbf{3 , 4 7 2}$. After dividing the total cost by its complexity, the cost for each complexity is IDR 5,301 .

\section{CONCLUSION}

Developing a school information system is certainly related to costs. Appropriate cost allocation is needed so that finance is well managed. Therefore, the authors analyze the unit cost (unit cost) with the $\mathrm{ABC}$ model (Activity Based Costing) to determine the standard costs of developing information systems. The ABC method bases the calculation of costs on the imposition of activity costs, so that the resulting costs are the result of the costs of all activities carried out on the development of Information Systems. In addition, costs can also be calculated for each complexity, as the complexity of information systems is a standard unit in the software world. So that in addition to getting prices and costs for the development of information systems can also be a reference for the development of other information systems that only use the value of its complexity. After getting the total cost, the cost per complexity is calculated. The total cost is IDR 18,732,082.00, while the complexity is 3,472 . After dividing the total cost by its complexity, the cost for each complexity is IDR 5,395 . With this, schools are expected to be able to 
manage finances for developing information systems effectively

\section{REFERENCES}

(INKINDO)., Dewan Pengurus Nasional Ikatan Nasional Konsultan Indonesia. (2018.). Pedoman Standard Minimal Tahun 2019.

Dyah, P. (2018). Analisis Perhitungan Biaya Pengembangan Perangkat Lunak Pemerintah: Studi Kasus Pada Pusintek, Kementerian Keuangan. Subtansi Vol 2.

Hilfi Lukman dkk. (2015). Perbedaan Perhitungan Unit Cost dengan Menggunakan Metode Activity Based Costing (ABC) dan Metode Doubel Distribution (DD) untuk Pasien Tb Paru Kategori 2 di Instalasi Rawat Jalan dan Rawat Inap Rumah Sakit Paru. . JSK Vol 2.

Islahuzzaman. (2011). Activity Based Costing Teori dan Aplikasi. Bandung: Alfabeta.

Mursyidi. (2010). Akuntansi Biaya: Conventional Costing, Just in Time, dan Activity-Based Costing. Bandung: PT Refika Aditama.

Perpres Nomor 16 Tahun 2018. (n.d.).

Setyaningrum, S. (2014). Analisis Perhitungan Biaya Satuan (Unit Cost) Dengan Model Activity Based Costing (Abc) Untuk Menentukan Standar Biaya Di SMK Negeri 3 Kota Tangerang Selatan. 
THIS PAGE INTENTIONALLY LEFT BLANK 